\title{
Effect of Cobalt and Different Organic Fertilizers on Cowpea (Vigna unguiculata) production
}

\author{
${ }^{1}$ Nadia Gad and ${ }^{2}$ Mohamed K. Rakha
}

${ }^{I}$ Plant Nutrition Dept., Agricultural and Biological Research Division, National Research Centre, 33 El Buhouth St., (Former El Tahrir St.) 12622 Dokki, Giza, Egypt.

${ }^{2}$ Self Pollinated Vegetable Crops Research Department, Horticulture Research Institute, Agriculture Research Centre, Giza, Egypt

Received: 30 Sept. 2019 / Accepted 10 Nov. 2019 / Publication date: 20 Nov. 2019

\begin{abstract}
Two field experiments were carried out to study the influence of cobalt $(0,8 \mathrm{ppm})$ and different organic fertilizers sources (Control, Chicken manure, Farmyard manure and Cotton compost waste) on cowpea production. Experiments were conducted at Research and Production Station, National Research Centre, El-Nubaria region, Behera Governorate, Delta Egypt, in two successive seasons of 2016 and 2017 under drip irrigation system. The experimental design was a split plot design with three replications.

The obtained results can be summarized as the following:

-Cobalt supplement significantly increased nitrogenase enzyme activity which was parallel and related to the increased nodules number, weights and its efficiency especially with chicken manure.

-The superior cowpea growth and yield parameters were attained in plants which supplied with $8 \mathrm{ppm}$ cobalt and chicken manure followed by farmyard manure while cotton compost was the lowest ones. -Application of cobalt at $8 \mathrm{ppm}$ to all studied organic fertilizers enhanced cowpea nodulation rate, growth and seeds yield quantity and its quality.
\end{abstract}

Keywords: cowpea, cobalt, organic fertilizers, seed yield quantity and quality.

\section{Introduction}

Cowpea is an important annual seeds legume. Cowpea production meets the food requirements of the people as a vegetable. Cowpea seeds are required as a nutrition component in the human diet as well as a nutritious livestock feed. Comparing with other cereal grains, lysine and tryptophan amino acids are rich in cowpea seeds. So, cowpea seed is an extender of animal proteins and valuable nutritional complement to cereals.

Soils of Egypt are poor in organic matter exceeding 2\% (Balba, 1976). To conserve their low level of organic matter; Egyptian soils should receive about 82 million tons annually (Riad, 1982). With increasing the cost of mineral fertilizers and questions as to their future availability, there is renewed interest in organic fertilizers especially organic recycling to improve soil fertility and productivity (Parr and Hornick, 1990).

Abd El-Sabour and Abou El-Seoud (1996) added that previous organic waste composts significantly increased sunflower dry matter and seeds yield as well as seeds minerals composition.

Cobalt is a beneficial element for higher plants, although there is no evidence of the direct role. Cobalt is an essential element for legumes due to its essentiality for micro-organisms fixing atmospheric nitrogen (Evans and Kliwer, 1964). Cobalt is a central atom of vitamin $\mathrm{B}_{12}$ structural. Vitamin $\mathrm{B}_{12}$ is essential water - soluble vitamin. Vitamin $B_{12}$ is valuable for human and animal nutrition. Unlike other heavy metals, cobalt is saver for human consumption and up to $8 \mathrm{ppm}$ can be consumed on a daily basis without health hazard (Young, 1983). With the increasing in age cobalt does not accumulate in human body as the other heavy metals (Smith, 1991).

Angelove et al. (1993) found that, cobalt increased chlorophyll synthesis and photosynthesis rate. Cobalt stimulates the growth and development of pea plants. Jana et al. (1994) stated that better nodulation due to proper doses of cobalt resulted in better growth and yield of groundnut plants. To

Corresponding Author: Nadia Gad, Plant Nutrition Dept., Agricultural and Biological Research Division, National Research Centre, 33 El Buhouth St., (Former El Tahrir St.) 12622 Dokki, Giza, Egypt. E-mail: drnadiagad@yahoo.com 
increase cobalt uptake by the wheat plants grown on sandy loam soil, it should be supplied with nitrogen (Bibak 1994).

This response was higher when receiving farmyard manure (FYM) than in the untreated field. Ismail et al. (1996) showed that cattle manure at raters $8 \%$ increased the availability and uptake of Co, $\mathrm{Cu}, \mathrm{Zn}$ and $\mathrm{Fe}$ by maize plants.

Watson et al. (2001) pointed that cobalt significantly increased plant height, root dry weights, leaf area index, dry matter accumulation in shoot parts as well as pods yield in both cowpea and groundnuts compared with the control .Balachandar et al. (2003) pointed that cobalt is an necessary element to legumes. In particular for growth and yield of blackgram. Nadia Gad (2006 b) reported that the addition of cobalt in pea plant media magnified the benefit of nutrients uptake by plants. Cobalt also increased both fresh and dry weights of shoots and roots, nodules number and weight, content of macronutrients, micronutrients as well as yield, pods and seeds quality of pea plants.

Jayakumar et al. (2009b) found that cobalt at $50 \mathrm{mg} \mathrm{kg}^{-1}$ soil has a significant positive effect on soybean growth and nutrient absorption. Nadia Gad et al. (2014) showed that cobalt at $12 \mathrm{ppm}$ significantly increased nitrogenase enzyme activity which was parallel related to the increase nodules number and weight, minerals status in soybean seeds especially with $100 \%$ and $75 \%$ nitrogen. Finally, the additions of cobalt at $12 \mathrm{ppm}$ to the soil save $25 \%$ nitrogen fertilizer compared with untreated soybean plants.

Nadia Gad and Fekry Ali (2016) pointed that, the application of cobalt at 8 ppm with different sources of organic fertilizers significantly enhancing pea growth, seeds yield quantity and its quality. Jayakumar et al. (2018) showed that all minerals composition of blackgram were increased as cobalt addition to soil increased compared with control plants. The high values of $\mathrm{Mn}, \mathrm{Zn}$ and $\mathrm{Cu}$ in blackgram seeds were detected with cobalt at $50 \mathrm{mg} / \mathrm{kg}$ soil.

Therefore, this work aimed to study the effect of cobalt and different organic fertilizers on cowpea growth, seeds yield quantity and quality.

\section{Materials and Methods}

Two experiments were carried out to study the effect of cobalt and different organic fertilizers on the growth, yield quantity and quality of cowpea.

\section{Soil analysis:}

Physical and chemical properties of Nubaria soil samples as well as particle size distributions and soil moisture were determined as described by Blackmore et al.(1972). Soil PH, EC, cations and anions, organic matter, $\mathrm{CaCO}_{3}$, total nitrogen and available $\mathrm{P}, \mathrm{K}, \mathrm{Fe}, \mathrm{Mn}, \mathrm{Cu}$ were run according to Black et al. (1982). Determinations of soluble, available and total cobalt were determined according to method described by Cottenie et al. (1982). Some physical and chemical properties of Nubaria soil sample are shown in Tables (1a and $1 \mathrm{~b})$.

Table 1a: Some physical and chemical properties of El-Nobaria soil during 2016 season.

\begin{tabular}{|c|c|c|c|c|c|c|c|c|c|c|c|}
\hline \multicolumn{12}{|c|}{ Physical properties } \\
\hline \multicolumn{4}{|c|}{ Particle size distribution \% } & \multicolumn{8}{|c|}{ Soil moisture constant \% } \\
\hline Sand & Silt & Clay & \multicolumn{2}{|c|}{ Soil texture } & \multicolumn{2}{|c|}{ Saturation } & FC & \multicolumn{2}{|c|}{ WP } & \multicolumn{2}{|c|}{$\mathbf{A W}$} \\
\hline 70.8 & 25.6 & 3.6 & Sandy loam & & & & 19.2 & 6.1 & & 13 & \\
\hline \multicolumn{12}{|c|}{ Chemical properties } \\
\hline \multicolumn{12}{|c|}{ Soluble cations $\left(\mathrm{meq}^{-1} \mathrm{~L}\right)$} \\
\hline $\begin{array}{c}\mathrm{pH} \\
1: 2.5\end{array}$ & $\begin{array}{c}E C \\
\left(d^{-1} ~ m^{-1}\right)\end{array}$ & $\mathrm{CaCO3} \%$ & $\begin{array}{c}\text { OM } \\
\%\end{array}$ & $\mathbf{C a}^{++}$ & $\mathbf{M g}^{++}$ & $\mathbf{K}^{+}$ & $\mathbf{N a}^{+}$ & $\mathrm{HCO}_{3}^{-}$ & $\mathrm{CO}_{3}$ & $\mathrm{Cl}^{-}$ & $\mathrm{SO}_{4}=$ \\
\hline 8.49 & 1.74 & 3.4 & 0.20 & 0.8 & 0.5 & 1.6 & 1.80 & 0.3 & 0.0 & 1.9 & 0.5 \\
\hline \multicolumn{3}{|c|}{ Cobalt (ppm) } & & $\begin{array}{l}\text { Total } A \\
(\operatorname{mg} 10\end{array}$ & $\begin{array}{l}\text { vailable } \\
\mathrm{g}^{-1} \text { soil) }\end{array}$ & & \multicolumn{5}{|c|}{$\begin{array}{c}\text { Available micronutriments } \\
(\mathbf{p p m})\end{array}$} \\
\hline Soluble & \multicolumn{2}{|c|}{$\begin{array}{c}\text { Available } \\
488\end{array}$} & Total & $\mathbf{N}$ & $\mathbf{P}$ & $\mathbf{K}$ & $\mathrm{Fe}$ & Mn & Zn & & $\mathbf{C u}$ \\
\hline 0.35 & \multicolumn{2}{|c|}{4.88} & 9.88 & 15.1 & 13.3 & 4.49 & 4.46 & 2.71 & 4.52 & & 5.2 \\
\hline
\end{tabular}


Table 1b: Some physical and chemical properties of El-Nobaria soil during 2017 season.

\begin{tabular}{|c|c|c|c|c|c|c|c|c|c|c|c|}
\hline \multicolumn{12}{|c|}{ Physical properties } \\
\hline \multicolumn{5}{|c|}{ Particle size distribution \% } & \multicolumn{7}{|c|}{ Soil moisture constant \% } \\
\hline Sand & Silt & Clay & \multicolumn{2}{|c|}{ Soil texture } & \multicolumn{2}{|c|}{ Saturation } & FC & \multicolumn{2}{|c|}{ WP } & \multicolumn{2}{|c|}{ AW } \\
\hline 69.8 & 26.7 & 3.5 & \multicolumn{2}{|c|}{ Sandy loam } & \multicolumn{2}{|c|}{20.0} & 14.4 & 3.9 & & \multicolumn{2}{|c|}{10.5} \\
\hline \multicolumn{12}{|c|}{ Chemical properties } \\
\hline \multicolumn{12}{|c|}{ Soluble cations $\left(\mathrm{meq}^{-1} \mathrm{~L}\right)$} \\
\hline $\begin{array}{c}\text { pH } \\
1: 2.5\end{array}$ & $\begin{array}{c}E C \\
\left(d_{S} ~ m^{-1}\right)\end{array}$ & $\mathrm{CaCO3} \%$ & $\begin{array}{c}\text { OM } \\
\%\end{array}$ & $\mathrm{Ca}^{++}$ & $\mathbf{M g}^{++}$ & $\mathbf{K}^{+}$ & $\mathrm{Na}^{+}$ & $\mathrm{HCO}_{3}^{-}$ & $\mathrm{CO}_{3}$ & $\mathrm{Cl}^{-}$ & $\mathrm{SO}_{4}=$ \\
\hline 8.00 & 1.00 & 3.17 & 0.19 & 0.9 & 1.4 & 5.4 & 3.26 & 0.00 & 1.18 & 6.6 & 2.4 \\
\hline \multicolumn{3}{|c|}{ Cobalt (ppm) } & \multicolumn{4}{|c|}{$\begin{array}{l}\text { Total available } \\
\qquad\left(\mathrm{mg} 100 \mathrm{~g}^{-1} \text { soil }\right)\end{array}$} & \multicolumn{5}{|c|}{$\begin{array}{l}\text { Available micronutriments } \\
\qquad(\text { ppm) }\end{array}$} \\
\hline Soluble & Av: & able & Total & $\mathbf{N}$ & $\mathbf{P}$ & $\mathbf{K}$ & $\mathbf{F e}$ & Mn & $\mathbf{Z n}$ & & $\mathbf{C u}$ \\
\hline 0.39 & & & 9.68 & 25.2 & 15.3 & 10.2 & 23.0 & 10.5 & 3.62 & & 5.22 \\
\hline
\end{tabular}

FC (Field capacity), WP (Welting point), AW (Available water).

Table 2: Some chemical properties of the studied organic fertilizers source

\begin{tabular}{|c|c|c|c|c|c|c|c|c|c|c|c|}
\hline \multirow[b]{2}{*}{ Organic source } & \multirow{2}{*}{$\begin{array}{c}\text { PH } \\
(1: 10)\end{array}$} & \multirow{2}{*}{$\begin{array}{c}E C \\
\left(\mathrm{dSm}^{-1}\right)\end{array}$} & \multirow{2}{*}{$\begin{array}{l}\mathrm{C} / \mathrm{N} \\
\text { ratio }\end{array}$} & \multirow{2}{*}{$\begin{array}{l}\text { O.M } \\
(\%)\end{array}$} & \multirow{2}{*}{$\begin{array}{c}\text { Total } \\
\text { Nitrogen } \\
(\%)\end{array}$} & \multicolumn{2}{|c|}{$\%$} & \multicolumn{4}{|c|}{ PPM } \\
\hline & & & & & & $\mathbf{P}$ & $\mathbf{K}$ & $\mathrm{Fe}$ & Mn & $\mathbf{C u}$ & Zn \\
\hline Chicker & 7.12 & 2.72 & 13.70 & 28.1 & 1.88 & 0.836 & 0.938 & 486 & 32.5 & 26.1 & 30.8 \\
\hline Farmyard manure & 6.90 & 4.10 & 14.72 & 2.72 & 2.06 & 0.930 & 0.859 & 469 & 28.4 & 23.0 & 27.5 \\
\hline Cotton compost & 6.91 & 3.42 & 12.70 & 24.9 & 1.86 & 1.189 & 1.302 & 446 & 24.9 & 19.9 & 24.2 \\
\hline
\end{tabular}

\section{Experimental works:}

Two field experiments were conducted in the Research and Production Station, National Research Centre, El-Nubaria region, Behera Governorate, Delta Egypt, under drip irrigation (50 cm apart) during two successive seasons of 2016 and 2017. The sandy loam soil with plot area consists of 35 meter in 10 $\mathrm{m}$ length and $3.5 \mathrm{~m}$ width. Calcium super phosphate $(15.5 \%)$ at the rate of $150 \mathrm{~kg} \mathrm{P}_{2} \mathrm{O}_{5} / \mathrm{fed}$ and potassium sulphate $\left(48 \% \mathrm{k}_{2} \mathrm{O}_{2}\right)$ at the rate of $100 \mathrm{~kg} / \mathrm{fed}$ as well as studied organic fertilizer were added during soil preparation.

Seeds of cowpea (Vigna urguiculata var Karim 7) was inoculated prior to sowing with a specific strain of rhizobium (Rhizobium melitota). Seeds were sown on 7, 9 $9^{\text {th }}$ April, 2016 and 2017 summer seasons. According Nadia Gad et al. (2013) cowpea plants irrigated once with cobalt at $8 \mathrm{PPm}$. Cobalt application was the main factor while the organic fertilizers the sub-main one.

A number of 8 treatments were concluded:

1) Control: received only recommended doses by Ministry of Agriculture of mineral fertilizers.

2) Chicken manure (33.5 $\mathrm{N}$ unit)

3) Farmyard manure (33.5 N unit)

4) Cotton compost waste (33.5 N unit)

5) Control: received only recommended doses by Ministry of Agriculture of mineral fertilizers + 8 ppm cobalt

6) Chicken manure ( $33.5 \mathrm{~N}$ unit) +8 ppm cobalt

7) Farmyard manure (33.5 N unit) +8 ppm cobalt

8) Cotton compost waste ( $33.5 \mathrm{~N}$ unit) +8 ppm cobalt

Each treatment was represented by 3 plots area, consisting of three rows. Each row consisting of ten plants.

All required agricultural managements for plants growth and production were carried out as recommended by Ministry of Agriculture. The experimental design was a split plot design with three replications.

\section{Measurement nodulation parameters:}

After 50 days from sowing, nodulation rate was record i.e. number of both total and active nodules as well as its biomass. Also nitrogenase enzyme was determined according to Hardy et al. (1968). 


\section{Measurement of plant vegetative growth:}

After 75 days from sowing to study the vegetative growth parameters expressed as plant height, number of branches and leaves, leaves area, root length as well as fresh and dry weights of both shoots and roots of 30 plants (10 plants from each plot) were determined according to FAO (1980).

\section{Measurement of pods and seeds yield:-}

After 105 days from sowing, pods and seeds yield and its quality such as number of pods per plant, pod length, pod width, fresh weight of 100 seeds and total yield (ton/fed) were determined according to Gabal et al. (1984).

\section{Measurements of Nutritional status:}

In cowpea seeds, macronutrients $(\mathrm{N}, \mathrm{P}$ and $\mathrm{K})$ and micronutrients $(\mathrm{Fe}, \mathrm{Mn}, \mathrm{Zn}$ and $\mathrm{Cu}$ ) as well as cobalt content were determined according to Cottenie et al. (1982).

\section{Measurement of Chemical constituents:}

In cowpea seeds, total proteins, total carbohydrates, total soluble sugars, total soluble solids as well as vitamins $\mathrm{A}$ and $\mathrm{C}$ were determined according to A.O.A.C (1995).

\section{Statistical Analysis:}

Data were subjected to analysis of variance (ANOVA) according to Gomez and Gomez (1984), using Costat software program Version 6.303 (2004). For comparing among means, Duncan's multiple range test at 0.05 probability level was used.

\section{Results and Discussion}

The obtained data clearly indicated that Chicken manure was the superior treatment followed by Farmyard manure, NPK as a control and Cotton compost. The lowest values of all cowpea studied parameters were obtained by cotton compost waste.

\section{Nodulation parameters:}

Data given in Table (3) reveal that cobalt has a significant promotive effect on cowpea nodules parameters such as total nodules number and weight per plant as well as active nodules number and weight per plant with all studied organic fertilizer. Data also show that the greatest values of nodulation parameters with chicken manure. These results are in harmony with those obtained by Nasef $\boldsymbol{e t} \boldsymbol{a l}$. (2008) they found that cobalt at $0.16 \mathrm{~g}^{-1}$ level had a significant higher nodule number and weight, nodule nitrogen content, leghemoglobin content, total biomass production and seeds yield of peanut compared with control.

Table 3: Cowpea nodulation parameters as affected by cobalt under different organic fertilizers during 2016 and 2017 seasons.

\begin{tabular}{|c|c|c|c|c|c|c|c|c|c|c|}
\hline \multirow[b]{2}{*}{ Treatments } & \multicolumn{5}{|c|}{2016} & \multicolumn{5}{|c|}{2017} \\
\hline & $\begin{array}{l}\text { Total no } \\
\text { Number }\end{array}$ & $\begin{array}{l}\text { es/plant } \\
\text { Fresh } \\
\text { weight } \\
\text { (g) }\end{array}$ & $\begin{array}{l}\text { Active no } \\
\text { Number }\end{array}$ & $\begin{array}{l}\text { les/plant } \\
\text { Fresh } \\
\text { weight } \\
\text { (g) }\end{array}$ & $\begin{array}{c}\text { Nitrognase } \\
\text { Mmol } \\
\left(\mathrm{C}_{2} \mathrm{H}_{2} /(\mathrm{gm})\right.\end{array}$ & $\begin{array}{l}\text { Total no } \\
\text { Number }\end{array}$ & $\begin{array}{l}\text { les/plant } \\
\text { Fresh } \\
\text { weight } \\
\text { (g) }\end{array}$ & Active no & $\begin{array}{c}\text { ules/plant } \\
\text { Fresh } \\
\text { weight(g) }\end{array}$ & $\begin{array}{c}\text { Nitrogenase } \\
\text { Mmol } \\
\left(\mathrm{C}_{2} \mathrm{H}_{2} /(\mathrm{gm})\right.\end{array}$ \\
\hline \multicolumn{11}{|l|}{ Cobalt: } \\
\hline With cobalt & 60.03 & 4.92 & 24.25 & 2.55 & 20.5 & 57.75 & 4.78 & 22.34 & 2.43 & 18.90 \\
\hline Without cobalt & 49.20 & 3.97 & 19.04 & 2.01 & 18.0 & 47.05 & 3.83 & 16.96 & 1.89 & 16.68 \\
\hline LSD at $5 \%$ & 5.11 & 0.75 & 2.77 & 0.39 & 1.15 & 6.11 & 0.53 & 3.12 & 0.45 & 0.17 \\
\hline \multicolumn{11}{|l|}{ Fertilizers: } \\
\hline Control (NPK) & 51.05 & 4.10 & 19.83 & 2.11 & 17.20 & 49.25 & 3.95 & 17.98 & 2.02 & 15.95 \\
\hline Chicken manure & 67.75 & 5.48 & 27.14 & 2.75 & 21.80 & 65.45 & 5.31 & 24.76 & 2.64 & 20.30 \\
\hline $\begin{array}{l}\text { Farmyard } \\
\text { manure }\end{array}$ & 58.15 & 5.06 & 23.81 & 2.53 & 20.15 & 55.6 & 4.93 & 22.18 & 2.44 & 18.60 \\
\hline Cotton compost & 41.50 & 3.15 & 15.82 & 1.73 & 17.85 & 39.3 & 3.03 & 13.69 & 1.55 & 16.30 \\
\hline LSD at $5 \%$ & 4.17 & 0.97 & 1.13 & 0.24 & 0.42 & 7.12 & 0.32 & 1.17 & 0.20 & 1.13 \\
\hline
\end{tabular}

Results in Table (3) also indicate that cobalt has a vital role accompanied with the increase of nitrogenase enzyme activity with all studied organic fertilizers. Cobalt recorded the best rate with chicken manure while the lowest values with cotton compost. These results are good agreement with 
those obtained by Epstein (1972) who stated that cobalt as Co-enzyme chelated to four nitrogen atoms at the center of a prophyrin structure similar to that of iron in hemin. In rhizobium species, enzymes are primary responsible for the relationship to nodulation and atmospheric nitrogen fixation in legumes.

Table 4: Effect of the interactions (cobalt and organic fertilizers) on number and fresh weight of total nodules in cowpea during 2016 and 2017 seasons.

\begin{tabular}{|c|c|c|c|c|c|c|c|c|}
\hline \multirow{3}{*}{ Treatments } & \multicolumn{2}{|c|}{2016} & \multicolumn{2}{|c|}{2017} & \multicolumn{2}{|c|}{2016} & \multicolumn{2}{|c|}{2017} \\
\hline & $\begin{array}{l}\text { With } \\
\text { cobalt }\end{array}$ & $\begin{array}{c}\text { Without } \\
\text { cobalt }\end{array}$ & $\begin{array}{c}\text { With } \\
\text { cobalt }\end{array}$ & $\begin{array}{c}\text { Without } \\
\text { cobalt }\end{array}$ & $\begin{array}{l}\text { With } \\
\text { cobalt }\end{array}$ & $\begin{array}{c}\text { Without } \\
\text { cobalt }\end{array}$ & $\begin{array}{l}\text { With } \\
\text { cobalt }\end{array}$ & $\begin{array}{c}\text { Without } \\
\text { cobalt }\end{array}$ \\
\hline & \multicolumn{4}{|c|}{ No. of total nodules/plant } & \multicolumn{4}{|c|}{ Fresh weight of total nodules/plant (g) } \\
\hline \multicolumn{9}{|l|}{ Fertilizers: } \\
\hline Control (NPK) & 53.1 & 49.0 & 51.2 & 47.3 & 3.89 & 4.31 & 4.13 & 3.77 \\
\hline Chicken manure & 78.7 & 56.8 & 76.3 & 54.6 & 4.87 & 6.08 & 5.97 & 4.64 \\
\hline Farmyard manure & 64.3 & 52.0 & 61.5 & 49.7 & 4.22 & 5.90 & 5.79 & 4.06 \\
\hline Cotton compost & 44.0 & 39.0 & 42.0 & 36.6 & 2.91 & 3.39 & 3.21 & 2.85 \\
\hline LSD at $5 \%$ & \multicolumn{2}{|c|}{0.96} & \multicolumn{2}{|c|}{0.78} & \multicolumn{2}{|c|}{0.14} & \multicolumn{2}{|c|}{0.12} \\
\hline
\end{tabular}

Significant interactions were found between cobalt and organic fertilizers on the total nodules/plant (Table 4). The application of cobalt resulted in the maximum values of aforementioned when chicken manure was used. In this regard, cobalt has a vital role accompanied with the increase of nitrogenase enzyme activity with all studied organic fertilizers. Cobalt recorded the best values with chicken manure while the lowest ones with cotton compost. These results are in good agreement with those obtained by Epstein (1972) who stated that cobalt as Co-enzyme chelated to four nitrogen atoms at the center of a prophyrin structure similar to that of iron in hemin. In rhizobium species, enzymes are primary responsible for the relationship to nodulation and atmospheric nitrogen fixation in legumes.

\section{Vegetative growth:}

Cowpea growth parameters as affected by cobalt and different organic fertilizers after 75 days from sowing are given in Table (5). Data show that cobalt enhance, all cowpea growth parameters such as plant height, number of branches and leaves as well as fresh and dry weights of both shoots and roots with all organic fertilizers used. These observation are consistent with previous reports obtained by Nadia Gad (2006 a) who found that cobalt being with positive effect due to several induced effects in hormonal synthesis and metabolic activity, while it's reduce the activity of some enzymes such as peroxidase and catalase in tomato plants and hence increasing the anabolism rather than catabolism. Confirm these results Bibak (1994) who added that, winter wheat treated with cobalt and farmyard manure resulted the higher growth compared with control (N, P and K).

Table 5: Cowpea growth parameters as affected by cobalt under different organic fertilizers during 2016 and

\begin{tabular}{|c|c|c|c|c|c|c|c|}
\hline \multirow[t]{3}{*}{ Treatments } & \multicolumn{7}{|c|}{2016} \\
\hline & \multirow{2}{*}{$\begin{array}{l}\text { Plant height } \\
\text { (cm) }\end{array}$} & \multicolumn{2}{|c|}{ Number/plant } & \multicolumn{2}{|c|}{ Fresh weight/plant (g) } & \multicolumn{2}{|c|}{ Dry weight/plant (g) } \\
\hline & & Branches & Leaves & Shoot & Root & Shoot & Root \\
\hline \multicolumn{8}{|l|}{ Cobalt: } \\
\hline With cobalt & 48.28 & 8.00 & 27.50 & 33.50 & 4.74 & 16.35 & 1.67 \\
\hline Without cobalt & 42.73 & 6.25 & 24.50 & 28.8 & 4.08 & 14.06 & 1.43 \\
\hline LSD at $5 \%$ & 3.47 & NS & 2.13 & 3.15 & 0.45 & 1.13 & NS \\
\hline \multicolumn{8}{|l|}{ Fertilizers: } \\
\hline Control (NPK) & 42.95 & 7.5 & 25.5 & 30.25 & 3.75 & 13.95 & 1.27 \\
\hline Chicken manure & 50.95 & 8.0 & 28.5 & 35.05 & 5.50 & 18.41 & 1.99 \\
\hline Farmyard manure & 48.55 & 7.5 & 27.5 & 32.05 & 5.25 & 16.44 & 1.87 \\
\hline Cotton compost & 39.55 & 6.5 & 22.5 & 27.25 & 3.15 & 12.01 & 1.05 \\
\hline \multirow[t]{4}{*}{ LSD at $5 \%$} & 4.11 & NS & 2.00 & 2.13 & 0.75 & 1.30 & NS \\
\hline & \multicolumn{7}{|c|}{2017} \\
\hline & \multirow{2}{*}{$\begin{array}{l}\text { Plant height } \\
\text { (cm) }\end{array}$} & \multicolumn{2}{|c|}{ Number/plant } & \multicolumn{2}{|c|}{ Fresh weight/plant (g) } & \multicolumn{2}{|c|}{ Dry weight/plant (g) } \\
\hline & & Branches & Leaves & Shoot & Root & Shoot & Root \\
\hline \multicolumn{8}{|l|}{ Cobalt: } \\
\hline With cobalt & 46.25 & 7.75 & 26.00 & 31.73 & 5.01 & 15.51 & 1.47 \\
\hline Without cobalt & 40.75 & 6.25 & 22.50 & 27.25 & 3.88 & 13.33 & 1.25 \\
\hline LSD at $5 \%$ & 3.27 & NS & 5.13 & 2.20 & 0.75 & 1.12 & NS \\
\hline \multicolumn{8}{|l|}{ Fertilizers: } \\
\hline Control (NPK) & 41.05 & 7.5 & 24.0 & 28.7 & 3.5 & 13.25 & 1.23 \\
\hline Chicken manure & 49.5 & 8.0 & 27.0 & 33.65 & 5.30 & 17.69 & 1.67 \\
\hline Farmyard manure & 46.55 & 7.0 & 25.5 & 30.50 & 6.00 & 15.67 & 1.49 \\
\hline Cotton compost & 37.40 & 5.5 & 20.5 & 25.10 & 4.26 & 11.06 & 1.06 \\
\hline LSD at $5 \%$ & 2.14 & NS & 1.40 & 2.11 & 1.14 & 2.00 & NS \\
\hline
\end{tabular}


Data in Table (6) show that there was a significant effect due to the interaction between cobalt and organic fertilizers on plant height and dry weight of shoot. Cobalt significantly increased previous parameters when chicken manure was applied compared with the other treatments. In this connection, the smallest aforementioned parameters was recorded with the cotton compost treatment and/ or without cobalt. These observation are consistent with previous reports obtained by Nadia Gad (2006 a) who found that cobalt being with positive effect due to several induced effects in hormonal synthesis and metabolic activity, while it's reduce the activity of some enzymes such as peroxidase and catalase in tomato plants and hence increasing the anabolism rather than catabolism. Confirm these results Bibak (1994) who added that, winter wheat treated with cobalt and farmyard manure responses the higher growth compared with control (N, P and K).

Table 6: Effect of the interactions (cobalt and organic fertilizers) on plant height and shoot dry weight/plant in cowpea during 2016 and 2017 seasons.

\begin{tabular}{|c|c|c|c|c|c|c|c|c|}
\hline \multirow{3}{*}{ Treatments } & \multicolumn{2}{|c|}{2016} & \multicolumn{2}{|c|}{2017} & \multicolumn{2}{|c|}{2016} & \multicolumn{2}{|c|}{2017} \\
\hline & $\begin{array}{c}\text { With } \\
\text { cobalt }\end{array}$ & $\begin{array}{c}\text { Without } \\
\text { cobalt }\end{array}$ & $\begin{array}{c}\text { With } \\
\text { cobalt }\end{array}$ & $\begin{array}{c}\text { Without } \\
\text { cobalt }\end{array}$ & $\begin{array}{c}\text { With } \\
\text { cobalt }\end{array}$ & $\begin{array}{c}\text { Without } \\
\text { cobalt }\end{array}$ & $\begin{array}{c}\text { With } \\
\text { cobalt }\end{array}$ & $\begin{array}{c}\text { Without } \\
\text { cobalt }\end{array}$ \\
\hline & \multicolumn{4}{|c|}{ Plant height (cm) } & \multicolumn{4}{|c|}{ Shoot dry weight/plant (g) } \\
\hline \multicolumn{9}{|l|}{ Fertilizers: } \\
\hline Control (NPK) & 45.6 & 40.3 & 43.2 & 38.9 & 15.07 & 12.82 & 14.22 & 12.28 \\
\hline Chicken manure & 54.0 & 47.9 & 52.4 & 45.6 & 19.76 & 17.05 & 18.93 & 16.45 \\
\hline Farmyard manure & 51.7 & 45.4 & 49.6 & 43.5 & 17.65 & 15.23 & 16.91 & 14.42 \\
\hline Cotton compost & 41.8 & 37.3 & 39.8 & 35.0 & 12.90 & 11.12 & 11.96 & 10.16 \\
\hline LSD at $5 \%$ & \multicolumn{2}{|c|}{1.3} & \multicolumn{2}{|c|}{1.1} & \multicolumn{2}{|c|}{1.31} & \multicolumn{2}{|c|}{1.22} \\
\hline
\end{tabular}

\section{Yield characteristics:}

Data in Table (7) show that both Chicken manure and Farmyard manure significantly increased the studied yield parameters of cowpea such as pods number per plant, pods weight per plant, pod length pod width and 100 seeds weight. While cotton compost resulted the lowest ones. This may explained on the basis of results reported by Ogunlele et al. (2005) they stated that chicken manure improve the growth, yield and its quality of lettuce compared with untreated plants. Data in Table (7) also indicate that the addition of cobalt in plant media significantly induced all yield parameters with all studied organic fertilizers. These results are agree with those obtained by Nadia Gad et al. (2006 c) they stated that olive yield resulted the higher values with cobalt at $22.5 \mathrm{ppm}$ and farmyard manure compared with control under Rass Seder conditions.

Table 7: Cowpea yield parameters as affected by cobalt under different organic fertilizers during 2016 and 2017 seasons.

\begin{tabular}{|c|c|c|c|c|c|c|}
\hline \multirow[b]{2}{*}{ Treatments } & \multicolumn{6}{|c|}{2016} \\
\hline & $\begin{array}{c}\text { No. of pods } \\
\text { /plant }\end{array}$ & $\begin{array}{l}\text { Pods weight/plant } \\
\text { (g) }\end{array}$ & $\begin{array}{l}\text { Pod length } \\
\text { (cm) }\end{array}$ & $\begin{array}{l}\text { Pod width } \\
\text { (cm) }\end{array}$ & $\begin{array}{l}100 \text { seeds } \\
\text { weight }(g)\end{array}$ & $\begin{array}{l}\text { Seeds yield } \\
\text { (ton/fed) }\end{array}$ \\
\hline \multicolumn{7}{|l|}{ Cobalt: } \\
\hline With cobalt & 15.35 & 27.16 & 9.83 & 0.83 & 21.28 & 5.26 \\
\hline Without cobalt & 12.98 & 25.08 & 7.88 & 0.70 & 20.16 & 4.30 \\
\hline LSD at $5 \%$ & 1.50 & 1.12 & 1.40 & NS & 1.01 & 0.41 \\
\hline \multicolumn{7}{|l|}{ Fertilizers: } \\
\hline Control (NPK) & 13.35 & 25.35 & 8.6 & 0.70 & 19.98 & 4.55 \\
\hline Chicken manure & 17.80 & 30.54 & 10.45 & 0.96 & 24.64 & 5.53 \\
\hline Farmyard manure & 15.2 & 27.99 & 9.20 & 0.85 & 22.28 & 5.26 \\
\hline Cotton compost & 10.31 & 20.60 & 7.15 & 0.55 & 15.98 & 3.78 \\
\hline \multirow[t]{2}{*}{ LSD at $5 \%$} & 1.11 & 2.11 & 0.71 & NS & 2.20 & 0.25 \\
\hline & \multicolumn{6}{|c|}{2017} \\
\hline Treatments & $\begin{array}{c}\text { No. of pods } \\
\text { /plant }\end{array}$ & $\begin{array}{c}\text { Pods weight/plant } \\
\text { (g) }\end{array}$ & $\begin{array}{c}\text { Pod length } \\
(\mathrm{cm})\end{array}$ & $\begin{array}{c}\text { Pod width } \\
(\mathrm{cm})\end{array}$ & $\begin{array}{l}100 \text { seeds } \\
\text { weight }(\mathrm{g}) \\
\end{array}$ & $\begin{array}{c}\text { Seeds yield } \\
\text { (ton/fed) }\end{array}$ \\
\hline \multicolumn{7}{|l|}{ Cobalt: } \\
\hline With cobalt & 14.27 & 25.83 & 9.43 & 0.78 & 20.11 & 4.90 \\
\hline Without cobalt & 11.70 & 24.11 & 7.45 & 0.65 & 18.36 & 3.93 \\
\hline LSD at $5 \%$ & 2.12 & 1.31 & 1.15 & NS & 0.77 & 0.42 \\
\hline \multicolumn{7}{|l|}{ Fertilizers: } \\
\hline Control (NPK) & 12.00 & 24.94 & 8.1 & 0.65 & 18.96 & 4.33 \\
\hline Chicken manure & 16.50 & 29.28 & 9.95 & 0.85 & 23.0 & 4.98 \\
\hline Farmyard manure & 13.85 & 26.58 & 9.00 & 0.75 & 20.10 & 4.76 \\
\hline Cotton compost & 9.60 & 19.09 & 6.7 & 0.60 & 14.87 & 3.56 \\
\hline LSD at $5 \%$ & 2.30 & 1.55 & 0.41 & NS & 0.52 & 0.32 \\
\hline
\end{tabular}


Table 8: Effect of the interactions (cobalt and organic fertilizers) on number of pods /plant and seeds yield (ton/fed) in cowpea during 2016 and 2017 seasons.

\begin{tabular}{|c|c|c|c|c|c|c|c|c|}
\hline \multirow[b]{2}{*}{ Treatments } & \multicolumn{2}{|c|}{2016} & \multicolumn{2}{|c|}{2017} & \multicolumn{2}{|c|}{2016} & \multicolumn{2}{|c|}{2017} \\
\hline & $\begin{array}{c}\text { With } \\
\text { cobalt }\end{array}$ & $\begin{array}{c}\text { Without } \\
\text { cobalt } \\
\text { No. of } \\
\end{array}$ & $\begin{array}{c}\text { With } \\
\text { cobalt } \\
\text { ds /plant }\end{array}$ & $\begin{array}{c}\text { Without } \\
\text { cobalt }\end{array}$ & $\begin{array}{c}\text { With } \\
\text { cobalt }\end{array}$ & $\begin{array}{l}\text { Without } \\
\text { cobalt } \\
\text { Seeds yi }\end{array}$ & $\begin{array}{c}\text { With } \\
\text { cobalt } \\
\text { (ton/fed) }\end{array}$ & $\begin{array}{c}\text { Without } \\
\text { cobalt }\end{array}$ \\
\hline \multicolumn{9}{|l|}{ Fertilizers: } \\
\hline Control (NPK) & 14.02 & 12.50 & 13.00 & 11.00 & 4.985 & 4.112 & 4.780 & 3.881 \\
\hline Chicken manure & 19.70 & 15.90 & 18.40 & 14.60 & 6.098 & 4.960 & 5.413 & 4.553 \\
\hline Farmyard manure & 16.60 & 13.80 & 15.50 & 12.20 & 5.766 & 4.758 & 5.202 & 4.315 \\
\hline Cotton compost & 10.91 & 9.70 & 10.19 & 9.00 & 4.187 & 3.380 & 4.188 & 2.976 \\
\hline LSD at $5 \%$ & \multicolumn{2}{|c|}{0.52} & \multicolumn{2}{|c|}{0.47} & \multicolumn{2}{|c|}{0.065} & \multicolumn{2}{|c|}{0.59} \\
\hline
\end{tabular}

Cobalt and organic fertilizers were markedly interacted in affecting all studied traits of cowpea yield and its attributes in Table (8). In this regard, cobalt significantly increased yield and its attributes when chicken manure was applied compared with the other treatments. These results are agree with those obtained by Nadia Gad et al. $(2006 \mathrm{c}$ ) they stated that olive yield resulted the higher values with cobalt at 22.5 ppm and farmyard manure compared with control under Rass Seder conditions.

\section{Nutritional status:}

Data in Table (9) reveal that the chicken manure recorded the highest content of both macronutrients and micronutrients in cowpea seeds followed by farmyard manure. Cotton compost gave the lowest values. These results are agree with those obtained by Nanwai et al. (1998) they stated that organic fertilizers are play a vital role in increasing wheat minerals composition compared with inorganic ones. Confirm these results Arisha and Bradisi (1999) they found that organic fertilizers has a promotive effect on potato growth, yield and its quality and mineral composition under sandy soil conditions compared with inorganic ones.

Table 9: Nutritional status in cowpea seeds as affected by cobalt under different organic fertilizers during 2016 and 2017 seasons.

\begin{tabular}{|c|c|c|c|c|c|c|c|c|}
\hline \multirow{3}{*}{ Treatments } & \multicolumn{8}{|c|}{2016} \\
\hline & \multicolumn{3}{|c|}{ Macronutrients (\%) } & \multicolumn{4}{|c|}{ Micronutrients (ppm) } & \multirow{2}{*}{$\begin{array}{l}\text { Cobalt } \\
\text { (ppm) }\end{array}$} \\
\hline & $\mathbf{N}$ & $\mathbf{P}$ & $\mathbf{K}$ & Mn & $\mathbf{Z n}$ & $\mathbf{C u}$ & $\mathbf{F e}$ & \\
\hline \multicolumn{9}{|l|}{ Cobalt: } \\
\hline With cobalt & 3.55 & 0.422 & 1.460 & 30.78 & 21.55 & 27.23 & 159 & 3.14 \\
\hline Without cobalt & 2.82 & 0.398 & 1.30 & 28.48 & 19.63 & 24.98 & 163 & 1.18 \\
\hline LSD at $5 \%$ & 0.52 & NS & NS & 0.12 & 0.45 & 1.11 & 3.11 & 0.25 \\
\hline \multicolumn{9}{|l|}{ Fertilizers: } \\
\hline Control (NPK) & 3.02 & 0.330 & 1.34 & 29.65 & 19.55 & 25.15 & 163 & 2.02 \\
\hline Chicken manure & 3.74 & 0.460 & 1.67 & 33.20 & 24.00 & 29.75 & 170.5 & 2.57 \\
\hline Farmyard manure & 3.51 & 0.423 & 1.49 & 30.85 & 21.30 & 27.7 & 163 & 2.41 \\
\hline Cotton compost & 2.47 & 0.378 & 1.03 & 24.80 & 17.50 & 21.8 & 147.5 & 1.63 \\
\hline \multirow[t]{4}{*}{ LSD at 5\% } & 0.44 & NS & $\mathrm{NS}$ & 0.21 & 0.32 & 1.16 & 4.12 & 0.14 \\
\hline & \multicolumn{8}{|c|}{2017} \\
\hline & \multicolumn{3}{|c|}{ Macronutrients (\%) } & \multicolumn{4}{|c|}{ Micronutrients (ppm) } & Cobalt \\
\hline & $\mathbf{N}$ & $\mathbf{P}$ & K & Mn & Zn & $\mathbf{C u}$ & $\mathbf{F e}$ & (ppm) \\
\hline \multicolumn{9}{|l|}{ Cobalt: } \\
\hline With cobalt & 2.99 & 0.388 & 1.42 & 28.20 & 20.53 & 26.20 & 152.25 & 3.05 \\
\hline Without cobalt & 2.62 & 0.352 & 1.25 & 26.0 & 18.40 & 24.25 & 158.0 & 1.15 \\
\hline LSD at $5 \%$ & 0.17 & NS & NS & 0.35 & 0.24 & 1.19 & 4.12 & 0.35 \\
\hline \multicolumn{9}{|l|}{ Fertilizers: } \\
\hline Control (NPK) & 2.71 & 0.359 & 1.28 & 26.80 & 18.25 & 24.15 & 160 & 2.00 \\
\hline Chicken manure & 3.23 & 0.408 & 1.62 & 29.80 & 22.70 & 28.95 & 161.5 & 2.51 \\
\hline Farmyard manure & 3.04 & 0.372 & 1.45 & 27.75 & 20.40 & 26.80 & 154.5 & 2.37 \\
\hline Cotton compost & $2 . .27$ & 0.342 & 0.99 & 24.05 & 16.50 & 21.00 & 144.5 & 1.52 \\
\hline LSD at $5 \%$ & 0.32 & NS & NS & 0.73 & 0.32 & 1.41 & 5.17 & 0.17 \\
\hline
\end{tabular}

Data in Table (9) also indicate that the addition of cobalt in plant media significantly increased the content of macronutrients $(\mathrm{N}, \mathrm{P}$ and $\mathrm{K}$ ) as well as micronutrients ( $\mathrm{Fe}, \mathrm{Mn}, \mathrm{Zn}$ and $\mathrm{Cu}$ ) with all studied organic fertilizers. These results are confirmed by Jana et al. (1994) they pointed that cobalt application resulted the better status of all minerals in groundnut seeds compared with control. Jayakumar et al. (2018) added that as cobalt addition to soil, all nutrients status of blackgram significantly increased. The high values of seeds content with cobalt at $50 \mathrm{mg} / \mathrm{kg}$ soil. 


\section{Chemical constituents:}

The amount of total proteins, total carbohydrates, total soluble sugars along with vitamin "C" and vitamin " $\mathrm{A}$ " in cowpea seeds as affected by cobalt and different organic fertilizers are given in Table (10). Results clearly indicate that all the mentioned parameters were significantly increased by cobalt with organic fertilizers used. Cobalt increased all chemical contents as a quality of cowpea seeds. These results are in harmony with those obtained by Nadia Gad and Nagwa Hassan (2013) they pointed that cobalt supplement with different organic fertilizers improves chemical contents of sweet pepper fruits. Confirm these results Griffths and Lunce (2001) they stated that, for human, high vitamin " $C$ " dietary, intake correlates with reduced gastric cancer risk. Vitamin " $\mathrm{A}$ " is an antioxidant and its essential to human growth normal physiological functions, health of the skin as well as mascus membranes.

Table 10: Chemical constituents in cowpea seeds as affected by cobalt under different organic fertilizers during 2016 and 2017 seasons.

\begin{tabular}{|c|c|c|c|c|c|c|c|c|c|c|}
\hline \multirow[b]{2}{*}{ Treatments } & \multicolumn{5}{|c|}{2016} & \multicolumn{5}{|c|}{2017} \\
\hline & $\begin{array}{c}\text { Total } \\
\text { protein } \\
(\%)\end{array}$ & $\begin{array}{c}\text { Total } \\
\text { carbohy- } \\
\text { drate } \\
(\%)\end{array}$ & $\begin{array}{c}\text { Total } \\
\text { soluble } \\
\text { sugars } \\
\% \\
\end{array}$ & $\begin{array}{c}\text { Vitamin } \\
\mathrm{C} \\
(\mathrm{mg} / \mathbf{1 0 0 g} \\
\text { fw) }\end{array}$ & $\begin{array}{c}\text { Vitamin } \\
A \\
(\mathrm{mg} / 100 \mathrm{~g} \\
\text { fw) }\end{array}$ & $\begin{array}{c}\text { Total } \\
\text { protein } \\
\%\end{array}$ & $\begin{array}{c}\text { Total } \\
\text { carbohy- } \\
\text { drate } \%\end{array}$ & $\begin{array}{c}\text { Total } \\
\text { soluble } \\
\text { sugars } \\
(\%) \\
\end{array}$ & $\begin{array}{c}\text { Vitamin } \\
\mathrm{C} \\
(\mathrm{mg} / 100 \mathrm{~g} \\
\text { fw) }\end{array}$ & $\begin{array}{c}\text { Vitamin } \\
A \\
(\mathbf{m g} / \mathbf{1 0 0 g} \\
\text { fw) }\end{array}$ \\
\hline \multicolumn{11}{|l|}{ Cobalt: } \\
\hline With cobalt & 24.33 & 54.00 & 12.64 & 4.27 & 3.40 & 23.28 & 54.20 & 12.28 & 4.12 & 3.26 \\
\hline $\begin{array}{l}\text { Without } \\
\text { cobalt }\end{array}$ & 22.40 & 51.88 & 10.12 & 3.84 & 2.18 & 22.15 & 53.55 & 9.83 & 3.66 & 2.08 \\
\hline LSD at $5 \%$ & 1.12 & 2.00 & NS & 0.21 & 0.52 & 1.00 & 0.32 & NS & 0.17 & 0.42 \\
\hline \multicolumn{11}{|l|}{ Fertilizers: } \\
\hline $\begin{array}{l}\text { Control } \\
(\mathrm{NPK})\end{array}$ & 22.55 & 52.10 & 10.63 & 3.85 & 1.98 & 22.00 & 52.90 & 15.11 & 3.70 & 1.86 \\
\hline $\begin{array}{l}\text { Chicken } \\
\text { manure }\end{array}$ & 25.60 & 55.65 & 13.14 & 4.79 & 3.91 & 24.95 & 56.25 & 12.89 & 4.65 & 3.80 \\
\hline $\begin{array}{l}\text { Farmyard } \\
\text { manure }\end{array}$ & 24.20 & 53.15 & 12.67 & 4.52 & 3.33 & 23.45 & 54.15 & 11.46 & 4.38 & 3.24 \\
\hline $\begin{array}{l}\text { Cotton } \\
\text { compost }\end{array}$ & 21.10 & 50.85 & 9.70 & 3.07 & 1.96 & 20.45 & 52.20 & 9.46 & 2.84 & 1.70 \\
\hline LSD at 5\% & 2.20 & 1.4 & NS & 0.35 & 0.42 & 0.94 & 0.42 & NS & 0.25 & 0.51 \\
\hline
\end{tabular}

The interaction effect of organic fertilizers treatments and Cobalt significantly affected total protein, total carbohydrates, vitamin " $\mathrm{C}$ " and vitamin "A" as maximum values were obtained with combined treatment of chicken manure and 8ppm Cobalt (Table 11).

Table 11: Effect of the interactions (cobalt and organic fertilizers) on total protein \%, total carbohydrate $\%$, vitamin C and vitamin A in cowpea seeds during 2016 and 2017 seasons.

\begin{tabular}{|c|c|c|c|c|c|c|c|c|}
\hline \multirow[b]{2}{*}{ Treatments } & \multicolumn{2}{|c|}{2016} & \multicolumn{2}{|c|}{2017} & \multicolumn{2}{|c|}{2016} & \multicolumn{2}{|c|}{2017} \\
\hline & $\begin{array}{l}\text { With } \\
\text { cobalt }\end{array}$ & $\begin{array}{l}\text { Without } \\
\text { cobalt } \\
\text { Total pro }\end{array}$ & $\begin{array}{l}\text { With } \\
\text { cobalt } \\
\text { tein }(\%)\end{array}$ & $\begin{array}{c}\text { Without } \\
\text { cobalt }\end{array}$ & $\begin{array}{l}\text { With } \\
\text { cobalt }\end{array}$ & $\begin{array}{c}\text { Without } \\
\text { cobalt } \\
\text { Total carb }\end{array}$ & $\begin{array}{l}\text { With } \\
\text { cobalt } \\
\text { ydrate (c }\end{array}$ & $\begin{array}{l}\text { Without } \\
\text { cobalt }\end{array}$ \\
\hline \multicolumn{9}{|l|}{ Fertilizers: } \\
\hline Control (NPK) & 23.8 & 21.3 & 22.7 & 21.3 & 53.0 & 51.2 & 53.1 & 52.7 \\
\hline Chicken manure & 26.7 & 24.5 & 25.7 & 24.2 & 57.1 & 54.2 & 56.7 & 55.8 \\
\hline Farmyard manure & 25.3 & 23.1 & 23.9 & 23.0 & 54.2 & 52.1 & 54.3 & 54.0 \\
\hline Cotton compost & 21.5 & 20.7 & 20.8 & 20.1 & 51.7 & 50.0 & 52.7 & 51.7 \\
\hline LSD at $5 \%$ & \multicolumn{2}{|c|}{1.2} & \multicolumn{2}{|c|}{1.5} & \multicolumn{2}{|c|}{2.5} & \multicolumn{2}{|c|}{2.2} \\
\hline & \multicolumn{4}{|c|}{ Vitamin C (mg/100g fw) } & \multicolumn{4}{|c|}{ Vitamin A ( mg/100g fw) } \\
\hline Fertilizers: & & & & & & & & \\
\hline Control (NPK) & 3.99 & 3.71 & 3.87 & 3.52 & 2.33 & 1.62 & 2.21 & 1.51 \\
\hline Chicken manure & 5.01 & 4.56 & 4.98 & 4.32 & 4.88 & 2.93 & 4.72 & 2.87 \\
\hline Farmyard manure & 4.86 & 4.17 & 4.67 & 4.09 & 4.19 & 2.47 & 4.08 & 2.39 \\
\hline Cotton compost & 3.22 & 2.91 & 2.95 & 2.72 & 2.21 & 1.70 & 2.01 & 1.56 \\
\hline LSD at $5 \%$ & \multicolumn{2}{|c|}{0.22} & \multicolumn{2}{|c|}{0.19} & \multicolumn{2}{|c|}{0.13} & \multicolumn{2}{|c|}{0.24} \\
\hline
\end{tabular}

The cotton compost plots without Cobalt application gave the smallest total protein, total carbohydrates, vitamin " $\mathrm{C}$ " and vitamin " $\mathrm{A}$ ". Cobalt increased all chemical contents as a quality of cowpea seeds. These results are in harmony with those obtained by Nadia Gad and Nagwa Hassan (2013) they pointed that cobalt supplement with different organic fertilizers improves chemical contents of sweet pepper fruits. Also Griffiths and Lunce (2001) they stated that, for human, high vitamin "C" dietary, intake 
correlates with reduced gastric cancer risk. Vitamin "A" is an antioxidant and its essential to human growth normal physiological functions, health of the skin as well as mascus membranes.

\section{Conclusion}

Cobalt is a promising element in the newly reclaimed soils. Organic fertilizers decreases soil $\mathrm{pH}$ and increases the availability of cobalt and micronutrients. Cobalt has a significant beneficial effect on cowpea growth, yield and seeds quality under organic fertilization.

\section{References}

A.O.A.C. 1995. Method of analysis. Association of Official Agriculture Chemists. 16th Ed., Washington, D.C.USA.

Abd El-Sabour, M.F. and M.A, Abou El-Seoud, 1996. Effect of organic compost addition on seasame growth, yield and chemical constituents. Agric Ecos and Environ, 60: 157-164.

Angelov, M., T. Tsonev, K. Dobrinova, V. Velikova and T. Stoynaova, 1993. Changes in some photosynthetic parameters in pea plants after treatment with cobalt. Phytosynthetica, 28: 289295.

Arisha, H.M. and A. Bradisi, 1999. Effect of mineral fertilizers and organic fertilizers on growth, yield and quality of potato under sandy soil conditions. Zagazig J. Agric. Res., 30: 1875-1899.

Balachandar, D., P. Nagarajan and S. Gunascharan, 2003. Effect of organic amendments and micronutrients on nodulation and yield of blackgram in acid soil. Legume Research, 26(3): 192195.

Balba, A.M., 1976. Soil fertility and fertilization. Dar El-Matboly El-Gadida. Alex. Egypt.

Bibak, A., 1994. Uptake of cobalt and manganese by winter wheat from a sandy loam soil with and without added farmyard manure and fertilizer nitrogen. Communications in soil Sci. and plant Analysis, 25: (15-16): 2675-2684.

Black, C.A., D.D. Evans, L.E. Ensminger, G.L. White and F.E. Clarck, 1982. "Methods of Soil Analysis", Part 2. Agron. Inc. Madispn Wise.

Blackmore, A.D., Jolly and R.H. Walser, 1972. Methods of Chemical Analisis of Soils. New Zealand. Soil Dureau. P A2.1, Dep.No. 10.

Cottenie, A., M. Verloo, L. Kiekens, G. Velgh and R. Camerlynck, 1982. Chemical analysis of plant and soil. Chemical Analysis of Plants and Soils. PP 44-45. State Univ. Ghent Belgium.

Epstein, E. 1972. "Mineral nutrition of plans": Principles and perspectives. John Wiley and Sons, Inc. New York.

Evans, H.J. and M. Kliwer, 1964. Vitamin $\mathrm{B}_{12}$ compounds in relation to the requirements of cobalt for higher plant and nitrogen fixing organisms. Ann. New York Acad. Sci. 112, Art., 2:732-755.

FAO 1980). Soil and plant testing as a basis of fertilizer recommendation. Soil Bull., 3812.

Gabal, M.R., I.M. Abd-Allah, F.M. Hass and S. Hassannen, 1984. Evaluation of some American tomato cultivars grown for early summer production in Egypt, Annals of Agriculture Science Moshtohor., 22: 487-500.

Gomez, K.A. and A.A. Gomez, 1984. Statistical Procedures for Agriculture Research. John Wiley \& Sons, New York (NY).

Griffths, H.R. and J. Lunce, 2001. Ascorbic acid in the 21th Century-more than a simple antioxidant

Environ. Toxicol. Pharmacol., 10:173-82.

Hardy, R.W.F., R.D. Holsten., E.K. Jackson and R.C. Burns, 1968. The Acetylene-Ethylene Assay for N2-Fixation: Laboratory and field Evaluation. Plant Physiology, (43):1185-1207

Ismail, A.S., M.F. Abdel-Sabour and H. Abou-Naga, 1996. Accumulation of heavy metals by plants as affected by application of organic wastes. Egypt. J. Soil. Sci., 36(1-4): 99-107.

Jana, P.K., S. Karmakar, S. Ghatak, A. Barik, A. Naybri, G. Souda, A.K. Mukher and B.K. Saren, 1994. Effect of cobalt and rhizobium on yield, oil content and nutrient concentration in irrigated summer groundnut, (Arachis Hypogaea). Indian Journal of Agriculture Science, 64:630-632

Jayakumar, K., C. Abduln Jaleel, Z. Chang-Xing and M.M. Azooz, 2009b. Cobalt induce varialtions in growth and pigment composition of Arachis hypogaea L. Academic J. of plant Sci., 2(2): 7477. 
Jayakumar, S., S. Richhariya B.K. Deb and G. Hasan, 2018. A multicomponent Neuronal Response Encodes the Larval Decision to Pupariate upon Amino Acid Starvation. J Neurosci. 21, 38(47):10202-10219.

Nadia Gad, 2006a. Increasing the efficiency of water consumption through cobalt application in the newly reclaimed soils. J. Apllied Sci. Research, 2 (11): 1081- 1091.Pakistan

Nadia Gad, 2006b. Increasing the efficiency of nitrogen fertilization through cobalt application two pea plant. Resarch J. Agric. Bio. Sci., 2(6): 433-442.Pakistan.

Nadia Gad and Nagwa Hassan, 2013. Response of growth and yield of sweet pepper (Capsicum annutm L) to cobalt nutrition. World Applied Journal, 2(5):760-765.

Nadia Gad, M.M. Aeshah and L.K. Bekbaye, 2013. Response of cowpea (Vigna Anguiculata) to cobalt nutrition. Middle-East Journal of Scientific Research 4(2): 177-184.

Nadia Gad, M.R. Abd El-Moez and M.H. El- Sherif, 2006 c. Physiological effect of cobalt on olive yield and fruit quality under Rass Seder conditions. Annals Agric. Sci., Ain Shams Univ., Cairo, 51(2): 335-346.

Nadia Gad, M.R. Abd El-Moez, Eman E. Aziz, Lyazzar Bckbyeva, Idres Hamad Atitaalla and Misni Surif, 2014. Influence of cobalt on soybean growth and production under different levels of nitrogen. Research Article CODEN (USA): IJPLCP, 5(3): 3278-32881.

Nadia Gad and M. E. Fekry Ali, 2016. Improvement of pea (Pisum sativum L.) production by optimization of cobalt under different organic fertilizers. International Journal of Phorm Tech Research CODEN (USA): IJRIF, ISSN: 0944-4304. ISSN (Online): 2455-8563, 9(12): 146154.

Nanwai, R.K., B.D. Sharma and K.D. Tanega, 1998. Role of organic and inorganic fertilizers for maximizing wheat yield sandy loam soils Crop Research, Hisar., 16 (2): 159-161.

Nasef, M.A., A.M. Abed El-Hameed, H.M. Salem and A.F. Abd El-Hamid, 2008. Efficiency of applied rates and methods of cobalt on growth, yield and elemental somposition of peanut plants growth on a sandy soil. Annals of Agricultural Science, Moshtohor, 42(2): 850-851.

Ogunlele, V.B., M.T. Masarirambi and S.M. Makysa, 2005. Effects of cattle manure application on pod yield and yield indices of okra (Abelmoschus esculentus L. Moench) in a semi-arid sub-tropical environmar. J. Food Agric. Environ, 3: 125-129.

Parr, J.F. and S.B. Hornick, 1990. Recent development in alternative agricultural in the united states. In proc. of $1^{\text {th }}$. Conf. on Kyussei Nature forming. KhonKean Univ. Tailand.

Riad, A., 1982. Potential sources of organic matter in Egypt. FAO, Soils Bull. 45:22-25. Roma. Italy.

Smith, R.M., 1991. Trace elements in human and animal nutrition. Micronutrients News and information, 11(4):9 (Abstr.).

Waston, R. J. , H. Roseylyn, T. Martin and E.S. Marc, 2001. Sinorhizobium meliloti cells require biotin and either cobalt methionine for growth. Applied and Environmental Microbiology, 86 (7): 3767-3770.

Young, R.S., 1983. Recent advances on cobalt in human nutrition. Micronutrients News and information, 3 (3): 2-5 (Abstr.). 